\title{
DE DE GRUYTER OPEN

\section{EMPIRICAL RESEARCH CONCERNING THE IMPACT OF THE PUBLIC INTERNAL AUDIT ON THE ACCOUNTING SYSTEM AND ITS RELIABILITY IN ROMANIAN UNIVERSITIES}

\author{
DRĂGUŞIN Cristina-Petrina \\ University of Craiova, Romania \\ DOMNIŞORU Sorin \\ University of Craiova, Romania \\ MIHAI Magdalena \\ University of Craiova, Romania
}

\begin{abstract}
:
The present paper is materialized in an empirical study concerning the impact of the internal audit on the accounting system and its reliability, in case of public universities in Romania. In order to achieve the study, it was necessary to know the different points of view of the representatives of the accounting departments of public institutions of academic education, using a statistical survey based on questionnaire. The research objectives were focused on obtaining conclusions regarding: the importance of internal auditing of the accounting system and its reliability; the extent to which the internal audit manages to provide reasonable assurances regarding the accounting and financial activity; the importance in auditing of the items related to the accounting activity; the assurance and the adequacy of the human resources allocated to the internal audit departments; the frequency with which the internal audit reports projects are modified in order to follow the audited structure recommendations; the extent to which the audit reports reflect the reality; the internal audit activity contribution in improving the accounting systems and their reliability in the Romanian universities.
\end{abstract}

Key words: internal audit, public universities, accounting system, internal control, reliability

\section{Introduction}

In the structure of any modern university, the internal audit has become an essential function with the responsibility to provide assurances regarding the proper functioning of the institution as a whole. The internal audit should enable the 
governance of the public institution of academic education to receive, from an alternative internal source, assurances according to which the processes within the university are carried out so that the probabilities of the existence of frauds, errors or inefficient practices are minimized.

Zakaria et al. (2006) consider the internal audit function as a component of the corporate governance, playing an important role in monitoring the financial reporting systems within the internal control system of higher education institutions.

In turn, Bielińska-Dusza (2011) believes that the internal audit has become an efficient management tool, aiming to improve the institution under a turbulent and unpredictable environment, permanently included in the arsenal of tools for managing it.

According to Turlea and Ştefănescu (2009) the public internal audit supervises and evaluates the efficiency of the risk management system and contributes to its improvement in order to bring added value to the institution. Moreover, each of the actors involved in this process needs the other, and together, they must provide to the public entity the appropriate framework to meet the exigent requirements of the public.

One of the levels on which the university internal audit operates is the accounting system. Given that the audit departments within the universities are intended to help the institutions management in the commitment of fulfilling its obligations, with the purpose of meeting the assumed goals, the present paper is materialized in an empirical study concerning the impact of internal audit on the accounting system and its reliability, in case of public universities in Romania.

\section{Methodology, Objectives and Research Hypotheses}

In order to gather information rich in pragmatic potential, we used the statistical survey based on a questionnaire as an observation method used in education.

The statistical survey has become an observation method increasingly used in social and human sciences, as it makes possible to collect, in a relative short time, information for a large number of features, which allows the depth characterization of the social phenomenon (Asandului, 2008, p. 23).

The general objectives pursued, through the empirical study based on a questionnaire, aimed to conclude on: the importance of the internal auditing of the accounting system and its reliability; the extent to which the internal audit activity manages to provide reasonable assurances regarding the financial and accounting activity; the importance in the audit process given to the accounting elements; the assurance and the adequacy of the human resources allocated to the university internal audit departments; the frequency with which the projects of the public internal audit reports are modified due to the recommendations of the audited structure and the causes that determine the formulation of such recommendations; the extent to which the university public internal audit reports reflect the reality and the degree of implementation of the recommendations made by the specialized departments; the 
contribution of the public internal audit to improving the accounting systems and their reliability in the academic education institutions.

The research was founded based on the following set of hypotheses, formulated after an extensive theoretical and methodological documentation, as well as a result of the pragmatic experience accumulated:

- hypothesis $\mathbf{1}$ - the specialized departments in the universities audit, at least once every three years, the accounting system and its reliability;

- hypothesis 2 - the internal audit of the accounting system and its reliability presents high importance;

- hypothesis 3 - the internal audit activity within universities manages to provide reasonable assurances especially regarding the legal and procedural compliance and less in matter of the other elements that characterize the accounting system;

- hypothesis 4 - meeting the requirements imposed by the managerial internal control standards is always pursued within the public internal audit missions conducted at the accounting structures level;

- hypothesis $\mathbf{5}$ - within the elements regarding the accounting system, which should be primarily audited, are to be found the accounting of the receivables, the payables and also the personnel expenses accounting;

- hypothesis 6 - the staff within the public internal audit departments of the universities should be supplemented and should receive professional training programs;

- $\quad$ hypothesis 7 - the projects of the public internal audit reports are frequently modified as a result of the recommendations made by the audited structure, from the need to clarify certain aspects that can be interpreted in a wrong way;

- $\quad$ hypothesis 8 - the findings issued through the public internal audit reports reflect, to a large extent, the reality;

- hypothesis $\mathbf{9}$ - at the level of the financial and accounting departments of the universities were very rarely found dysfunctions, as a result of the assessment made by the public internal audit;

- hypothesis $\mathbf{1 0}$ - the public internal audit activity helps relatively to improve the accounting system and its reliability.

Our questionnaire, as a tool of investigation, was designed as a set of 18 coherent and relevant questions, that help us to get a radiography of the impact of public internal audit on the accounting system in Romanian universities.

Considering the reluctance of the respondents and their extremely low percentage of response to the open questions, we have formulated closed questions and partially open questions, thus facilitating a shorter response time. In relation to the informational content that was desired to be obtained from the respondents, the questionnaire consisted in different type of questions such as: respondents' identification and classification questions, attitude or opinion questions, knowledge questions and filter type questions. Also, the manner of structuring the questions can 
be seen from another perspective, in relation to which we highlight the following categories: scale type questions with one answer allowed or with multiple answers allowed, hierarchical type of questions and also a response matrix question type. The questions were formulated in a simple and coherent manner so as to be understood by all the respondents, avoiding the words with vague or ambiguous meaning.

After formulating the questions, we used the "Google Forms" application, with which we conducted the online questionnaire. It debuted with an introduction through which we stated the research purpose, trying at the same time also to stimulate the subjects to participate to the study undertaken by us. Also, we stated clearly our intentions and the way in which the information were to be used, guaranteeing the anonymity and the confidentiality of the respondents.

In order to ensure that the questions were clear and properly understood, the questionnaire was initially tested on a sample of 7 people, and following the observations, we proceeded to disseminate it, as a link via email, to the heads of the financial and accounting departments in higher education institutions under the Ministry of Education and Scientific Research, along with some additional information. On this occasion, since we could not get the e-mail addresses of all the employees from the financial and accounting departments in universities, we appealed to the kindness of the leaders, addressing the request of sending the link of our questionnaire to their colleagues, in order to get as many responses as possible and, at the same time, to increase the relevance of the study.

So the general population considered for our study consisted of the representatives of financial and accounting departments within the 48 public institutions of academic education under the Ministry of Education and Scientific Research.

The subjects could complete the questionnaire in real time by simply accessing the link received by email, and finally, in order to deliver the answers, it was necessary to select the dedicated button "Submit". The answers were collected and centralized in an Excel file generated by the intelligent application. Starting from this file, we continued our investigative approach, by making relevant tables and graphs, to guide us in the direction of fundamenting the conclusions.

The collection and the primary processing of the data, obtained as a result of the research based on questionnaire, were conducted between 17th February 2015 and 7th May 2015. After applying the questionnaire, we managed to obtain a total of 116 responses, which we consider as relevant and satisfactory in the light of the arguments that we shall present in the followings.

\section{Empirical Results}

The first part of the questionnaire was dedicated to the identification and classification of the respondents. If we refer to a first variable, the position held within the financial and accounting departments of the universities, the structure of the respondents is presented according to Table 1. 
Table 1: The structure of the respondents according to their position within the financial and accounting departments of the universities

\begin{tabular}{|c|c|c|}
\hline \multicolumn{1}{|c|}{ Categories of respondents } & $\begin{array}{c}\text { Number of } \\
\text { respondents }\end{array}$ & Share \\
\hline Leaders of financial and accounting departments & 17 & $14,65 \%$ \\
\hline Management staff, other than heads of the departments & 23 & $19,83 \%$ \\
\hline Production staff & 76 & $65,52 \%$ \\
\hline \multicolumn{1}{|c|}{ Total } & $\mathbf{1 1 6}$ & $\mathbf{1 0 0 , 0 0 \%}$ \\
\hline
\end{tabular}

Source: Own processing

We can notice that the majority of the subjects who completed the questionnaire activate as production staff in the accounting structures in universities $(65.52 \%)$. We also had respondents among the management staff, other than the heads of the departments (chiefs of services, heads of offices), as well as financial and accounting departments leaders, in a lower percentage of $20 \%$ for each category. Despite this percentage, apparently quite low, if we correlate the number of respondents among the heads of the accounting structures (economic directors, accounting and financial directors, chief accountants), with the total number of accounting and financial departments leaders to which we have disseminated the questionnaire, we obtain a percentage of $35.42 \%$, which we consider as being representative.

If we refer to a second variable, the year in which the subjects last participated to an internal audit mission, as audited staff, the structure of the respondents is presented according to Table 2 .

We must note that $33.62 \%$ of the employed personnel in the financial and accounting departments of the universities pursued throught our investigative approach were audited last time in the year 2014, while $20.69 \%$ of the subjects responded that they last participated to an internal audit mission in the year 2015. Also, $19.83 \%$ of the respondents stated that they have never been audited, an aspect that we appreciate as being unfavourable, since the legislation stipulates the necesity of auditing the accounting system and its reliability, at least every three years. We consider this percentage too high raported to be about personnel hired in the year range of 20132015. On the next position in the ranking we find the financial-accounting staff that has been subjected to the audit process before the year of 2013 , with a share of $15.52 \%$. The minority share $(10.34 \%)$ is held by respondents who were subject to the audit during the year 2013. 
Table 2: The structure of the respondents according to the year in which the subjects last participated to an internal audit mission, as staff of the audited structure

\begin{tabular}{|c|c|c|}
\hline $\begin{array}{l}\text { The year in which the subjects were audited } \\
\text { last time }\end{array}$ & $\begin{array}{l}\text { Number of } \\
\text { respondents }\end{array}$ & Share \\
\hline $\ln 2015$ & 24 & $20,69 \%$ \\
\hline In 2014 & 39 & $33,62 \%$ \\
\hline In 2013 & 12 & $10,34 \%$ \\
\hline Before 2013 & 18 & $15,52 \%$ \\
\hline Never & 23 & $19,83 \%$ \\
\hline Total & 116 & $100,00 \%$ \\
\hline
\end{tabular}

Source: Own processing

Further, we followed the importance that the representatives of the accounting structures from universities assign to the internal audit activity of the accounting system and its reliability. The results obtained by centralizating all the opinions expressed by the respondents highlight that $75 \%$ of the respondents (87 people) assign a high importance to the internal auditing of the accounting system and its reliability, while a percentage of $20.69 \%$ of the subjects (24 people) consider that these audit missions have a medium importance. From the opposite perspective, a very small percentage of $4.31 \%$ of the respondents (5 people) believe that the accounting system internal auditing approaches present little importance. We appreciate these results as being gladdening as they suggest that the internal audit began to be perceived at its real value within the Romanian universities.

Table 3: The synthesis of the results regarding the assurances provided by the public internal audit

\begin{tabular}{|c|c|c|c|c|c|c|c|c|c|c|}
\hline \multicolumn{11}{|c|}{$\begin{array}{l}\text { Please indicate to what extent do you consider the activity of public internal audit in your } \\
\text { institution manages to provide reasonable assurances regarding the following elements: } \\
\text { (number of responses /share in total answers) }\end{array}$} \\
\hline & \multicolumn{2}{|c|}{$\begin{array}{l}\text { To a very } \\
\text { large } \\
\text { extent }\end{array}$} & \multicolumn{2}{|c|}{$\begin{array}{c}\text { To a large } \\
\text { extent }\end{array}$} & \multicolumn{2}{|c|}{ Relatively } & \multicolumn{2}{|c|}{$\begin{array}{c}\text { To a small } \\
\text { extent }\end{array}$} & \multicolumn{2}{|c|}{ At all } \\
\hline $\begin{array}{l}\text { management of the } \\
\text { university accounting }\end{array}$ & 27 & $23,28 \%$ & 30 & $25,86 \%$ & 36 & $31,03 \%$ & 20 & $17,24 \%$ & 3 & $2,59 \%$ \\
\hline $\begin{array}{l}\text { The compliance with the } \\
\text { legal and the procedural } \\
\text { framework regarding the } \\
\text { financial and accounting } \\
\text { activity }\end{array}$ & 39 & $33,62 \%$ & 36 & $31,03 \%$ & 21 & $18,10 \%$ & 17 & $14,66 \%$ & 3 & $2,59 \%$ \\
\hline $\begin{array}{l}\text { The accuracy of the } \\
\text { financial and accounting } \\
\text { activity and production }\end{array}$ & 18 & $15,52 \%$ & 45 & $38,79 \%$ & 30 & $25,86 \%$ & 20 & $17,24 \%$ & 3 & $2,59 \%$ \\
\hline
\end{tabular}




\begin{tabular}{|c|c|c|c|c|c|c|c|c|c|c|}
\hline $\begin{array}{c}\text { The degree of the results } \\
\text { compliance with the } \\
\text { objectives }\end{array}$ & 15 & $12,93 \%$ & 27 & $23,28 \%$ & 48 & $41,38 \%$ & 23 & $19,82 \%$ & 3 & $2,59 \%$ \\
\hline $\begin{array}{l}\text { The efficient functioning of } \\
\text { the internal control system } \\
\text { at the level of the financial } \\
\text { and accounting activity }\end{array}$ & 15 & $12,93 \%$ & 42 & $36,21 \%$ & 33 & $28,45 \%$ & 23 & $19,82 \%$ & 3 & $2,59 \%$ \\
\hline $\begin{array}{c}\text { The efficient functioning of } \\
\text { the leading system at the } \\
\text { financial and accounting } \\
\text { activity level }\end{array}$ & 18 & $15,52 \%$ & 21 & $18,10 \%$ & 47 & $40,51 \%$ & 27 & $23,28 \%$ & 3 & $2,59 \%$ \\
\hline
\end{tabular}

Subsequently, we asked the respondents to indicate the extent to which the public internal audit activity, within their universities, succeeds to provide reasonable assurances regarding factors such as: the organization and management of the university accounting; the compliance with the legal and the procedural framework regarding the financial and accounting activity; the accuracy of the financial and accounting activity and production; the degree of the results compliance with the objectives; the efficient functioning of the internal control system at the level of the financial and accounting activity; the efficient functioning of the leading system at the financial and accounting activity level.

The centralization of the results regarding the assurances provided by the public internal audit is presented numerically and in percentage in Table 3.

This information show that, from the perspective of the majority of the respondents, the internal audit activity within universities manages to provide reasonable assurances:

- to a very large extent - in terms of compliance with the legal and procedural framework regarding the financial and accounting activity;

- to a large extent - concerning not only the accuracy of the financial and accounting activity and production, but also the efficient functioning of its internal control system;

- relatively - regarding not only the organization and management of the university, the degree of the results compliance with the objectives, but also the efficient functioning of the leading system at the financial and accounting activity level.

However, we must not neglect, for each item, the percentage of respondents who awarded the qualification "to a small extent". The quantitative information in Table 3 show that this percentage is between $14.66 \%-23.28 \%$, which in our opinion should not be overlooked.

We also considered necessary and appropriate to insert, in the questionnaire, a question with the purpose of tracking the frequency of following the compliance with the requirements imposed by the internal/managerial control standards, within the university internal audit missions carried out at the level of the accounting structures. The summary of responses given to this question shows that the majority of 
subjects (54 persons - 46.55\%) confirmed tracking the requirements imposed by the internal/managerial control standards each time a public internal audit mission is carried out within the university accounting structure, while a percentage of $36.21 \%$ of the respondents (42 people) responded that such compliance is monitored periodically. Instead, a percentage of $17.24 \%$ of the respondents (20 people) affirmed that in the public internal audit missions undertaken at the accounting system, the fulfillment of the requirements imposed by these standards was monitored only to a small extent. We consider that these results are, to some extent, influenced by some confusions or vaguenesses in the proper perception by the respondents of what actually internal/managerial control represents.

Through the following two questions, we asked the respondents to rank six elements referring to the accounting activity, according to the importance they noticed the public internal auditors assign to them, within the audit missions, and also regarding the importance that they should assign to them from the subjects perspective. The elements relating to the accounting activity considered for ranking were: setting goals, planning, coordinating, monitoring and risk management in the accounting activity; establishing the attributions, functions, duties and the delegation of powers; covering with human resources the necessary for the accounting activity; the professional training and the personal skills of the employees performing the accounting activity; drawing up not only the own standards, procedures, documents and their circuit, but also identifying the persons authorized to carry out the operations related to the accounting activity; the compliance with the legal and the procedural framework concerning the accounting activity.

For the hierarchyzation, a hierarchical scale from 1-6 was used, ,1" denoting the most important element and ,6" the least important element. The summary of the results on the importance attributed by the public internal auditors, to the accounting activity elements is presented according to Table 4.

The points of view of the universities accounting and financial departments members, show that public internal auditors assign high importance to the folowing elements: the compliance with the legal and the procedural framework concerning the accounting activity, drawing up not only the own standards, procedures, documents and their circuit, but also identifying the persons authorized to carry out the operations related to the accounting activity, setting goals, planning, coordinating, monitoring and risk management in the accounting activity, establishing the attributions, functions, duties and the delegation of powers and a lesser importance to the following elements: covering with human resources the necessary for the accounting activity and the professional training and the personal skills of the employees performing the accounting activity. We can issue the opinion according to which this is not the

happiest situation since the focus is not really on performance, but rather on compliance. 
Table 4: The summary of the results on the importance attributed by the public internal auditors to the accounting activity elements

\begin{tabular}{|c|c|c|c|c|c|c|}
\hline \multicolumn{7}{|c|}{$\begin{array}{l}\text { Please arrange from } 1 \text { to } 6 \text { (1 - the most important, } 6 \text { - the least important) the following accounting } \\
\text { activity elements according to the importance assigned to them, in the missions, by public internal } \\
\text { auditors: }\end{array}$} \\
\hline & 1 & 2 & 3 & 4 & 5 & 6 \\
\hline \multirow{2}{*}{$\begin{array}{l}\text { Setting goals, planning, coordinating, } \\
\text { monitoring and risk management in the } \\
\text { accounting activity }\end{array}$} & 25 & 24 & 23 & 19 & 15 & 10 \\
\hline & $21,55 \%$ & $20,69 \%$ & $19,83 \%$ & $16,38 \%$ & $12,93 \%$ & $8,62 \%$ \\
\hline \multirow{2}{*}{$\begin{array}{l}\text { Establishing the attributions, functions, } \\
\text { duties and the delegation of powers }\end{array}$} & 22 & 21 & 17 & 20 & 17 & 19 \\
\hline & $18,96 \%$ & $18,10 \%$ & $14,66 \%$ & $17,24 \%$ & $14,66 \%$ & $16,38 \%$ \\
\hline \multirow{2}{*}{$\begin{array}{l}\text { Covering with human resources the } \\
\text { necessary for the accounting activity }\end{array}$} & 5 & 10 & 16 & 22 & 28 & 35 \\
\hline & $4,31 \%$ & $8,62 \%$ & $13,79 \%$ & $18,97 \%$ & $24,14 \%$ & $30,17 \%$ \\
\hline \multirow{2}{*}{$\begin{array}{l}\text { The professional training and the } \\
\text { personal skills of the employees } \\
\text { performing the accounting activity }\end{array}$} & 9 & 12 & 15 & 27 & 28 & 25 \\
\hline & $7,76 \%$ & $10,34 \%$ & $12,93 \%$ & $23,28 \%$ & $24,14 \%$ & $21,55 \%$ \\
\hline \multirow{2}{*}{$\begin{array}{l}\text { Drawing up not only the own standards, } \\
\text { procedures, documents and their circuit, } \\
\text { but also identifying the persons } \\
\text { authorized to carry out the operations } \\
\text { related to the accounting activity }\end{array}$} & 26 & 21 & 20 & 18 & 16 & 15 \\
\hline & $22,42 \%$ & $18,10 \%$ & $17,24 \%$ & $15,52 \%$ & $13,79 \%$ & $12,93 \%$ \\
\hline \multirow{2}{*}{$\begin{array}{l}\text { The compliance with the legal and the } \\
\text { procedural framework concerning the } \\
\text { accounting activity }\end{array}$} & 29 & 28 & 25 & 10 & 12 & 12 \\
\hline & $25,01 \%$ & $24,14 \%$ & $21,55 \%$ & $8,62 \%$ & $10,34 \%$ & $10,34 \%$ \\
\hline
\end{tabular}

Source: Own processing

Looking from the opposite perspective, the situation of the responses provided by the accounting and financial staff is presented according to Table 5 .

Table 5: The synthesis of the results on the importance assigned to the auditable elements by the representatives of the accounting departments within

\section{universities}

Please arrange from 1 to 6 (1 - the most important, 6 - the least important) the same elements according to the importance you consider the public internal auditors should assign to them in the missions:

\begin{tabular}{|c|c|c|c|c|c|c|}
\hline & 1 & 2 & 3 & 4 & 5 & 6 \\
\hline \multirow{2}{*}{$\begin{array}{c}\text { Setting goals, planning, coordinating, } \\
\text { monitoring and risk management in } \\
\text { the accounting activity }\end{array}$} & 10 & 19 & 26 & 21 & 20 & 20 \\
\hline & $8,63 \%$ & $16,38 \%$ & $22,41 \%$ & $18,10 \%$ & $17,24 \%$ & $17,24 \%$ \\
\hline \multirow{2}{*}{$\begin{array}{c}\text { Establishing the attributions, } \\
\text { functions, duties and the delegation } \\
\text { of powers }\end{array}$} & 32 & 19 & 16 & 15 & 17 & 17 \\
\hline & $27,59 \%$ & $16,38 \%$ & $13,78 \%$ & $12,93 \%$ & $14,66 \%$ & $14,66 \%$ \\
\hline \multirow{2}{*}{$\begin{array}{l}\text { Covering with human resources the } \\
\text { necessary for the accounting activity }\end{array}$} & 22 & 22 & 17 & 20 & 17 & 18 \\
\hline & $18,97 \%$ & $18,97 \%$ & $14,66 \%$ & $17,24 \%$ & $14,66 \%$ & $15,50 \%$ \\
\hline The professional training and the & 11 & 24 & 21 & 21 & 19 & 20 \\
\hline
\end{tabular}




\begin{tabular}{|c|r|r|r|r|r|r|}
\hline $\begin{array}{c}\text { personal skills of the employees } \\
\text { performing the accounting activity }\end{array}$ & $9,49 \%$ & $20,69 \%$ & $18,10 \%$ & $18,10 \%$ & $16,38 \%$ & $17,24 \%$ \\
\hline $\begin{array}{c}\text { Drawing up not only the own } \\
\text { standards, procedures, documents } \\
\text { and their circuit, but also identifying } \\
\text { the persons authorized to carry out } \\
\text { the operations related to the } \\
\text { accounting activity }\end{array}$ & 16 & 14 & 23 & 20 & 22 & 21 \\
\cline { 2 - 8 } & $13,79 \%$ & $12,07 \%$ & $19,83 \%$ & $17,24 \%$ & $18,97 \%$ & $18,10 \%$ \\
\hline $\begin{array}{c}\text { The compliance with the legal and the } \\
\text { procedural framework concerning the } \\
\text { accounting activity }\end{array}$ & $21,55 \%$ & $15,52 \%$ & $11,21 \%$ & $16,38 \%$ & $18,10 \%$ & $17,24 \%$ \\
\hline
\end{tabular}

We note that, according to most respondents, public internal auditors should pay:

- the highest importance - to establishing the attributions, functions, duties and delegation of powers, compliance with the legal and the procedural framework concerning the accounting activity, covering with human resources the necessary for the accounting activity;

- high importance - to the professional training and the personal skills of the employees performing the accounting activity;

- relative importance - to drawing up not only the own standards, procedures, documents and their circuit, but also identifying the persons authorized to carry out the operations related to the accounting activity and setting goals, planning, coordinating, monitoring and risk management in the accounting activity.

We appreciate the obtained results as encouraging, considering that these high aspirations suggest future trends at least interesting.

At question no. 8, the respondents were requested to rank ten elements regarding the university accounting system, in relation to the priority considered that it should be given to their auditing, depending on the associated risk.

After processing the results, we made the matrix of the collected responses, through which we could order the items that characterize the university accounting system, in terms of priority to auditing.

As shown in Figure 1, the respondents performed on the following hierarchy of the elements regarding the university accounting system, in relation to their priority to auditing: subsidies accounting (39 responses - 33.62\%), followed by receivables and debts accounting (32 responses - 27.59\%), the treasury accounting (40 responses $34.48 \%$ ), personnel expenses accounting (47 responses - $40.52 \%$ ), drawing up the quarterly and annual financial statements (29 responses - 25\%), the accounting recongnition of the inventory results (39 responses - 33.62\%), ensuring technical and operational evidence (39 responses - 33.62\%), fixed assets and investments accounting (58 responses - 50\%), materials accounting, including inventory objects (47 responses - $40.52 \%$ ) and, the last position, archiving the financial-accounting 
documents (97 responses - 83.62\%). We appreciate that the responses to this question are rather under the influence of the gross effort submitted by the respondents, than under the effect of the risk subtleties in these areas.

Figure 1: The ranking of the elements regarding the university accounting system through their priority to auditing

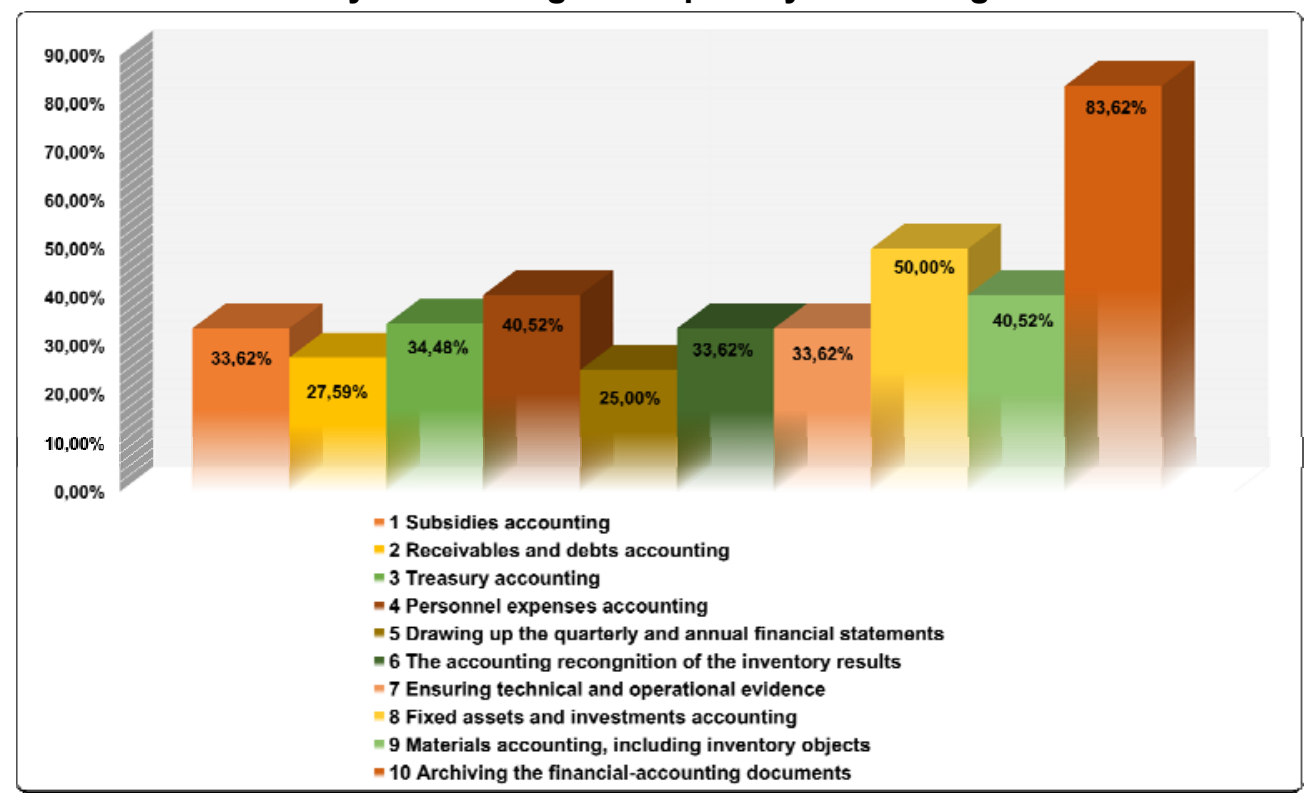

Source: Own projection

At the question regarding the professional training of the internal auditors within the universities, $56.40 \%$ of the subjects responded that the auditors are somewhat prepared, $41 \%$ declared that they are clearly well prepared, while $2.60 \%$ of the respondents have doubted about their professional training. Therefore, we can only apreciate that the relevant legal provisions in the field are not random.

Another aspect taken into account in our study relates to ensuring and adequacy of human resources allocated to internal audit departments within universities. The summary of the results shows us that most representatives of the universities accounting structures (34 people) declared that it must be recruited staff to keep the step with the evolution of the public internal audit activity, eventually younger staff. Also, a significant number of respondents stated that: it is necessary that the existing auditors atend vocational training programs and the experienced staff must be supplemented with younger staff. Conversely, $10.34 \%$ of the respondents believe that the structure should remain unchanged on considerations of experience, while $2.58 \%$ believe that the existing staff, in the public internal audit departments within universities, should be reduced naturally.

Within our survey, we found it necessary and useful to include also a question to evaluate the characteristics of the evidence collected by the university public 
internal auditors within the missions undertaken at the level of the accounting structures. The summary of these results is shown in Figure 2.

\section{Figure 2: The results regarding the characteristics of the evidence collected} by the university public internal auditors

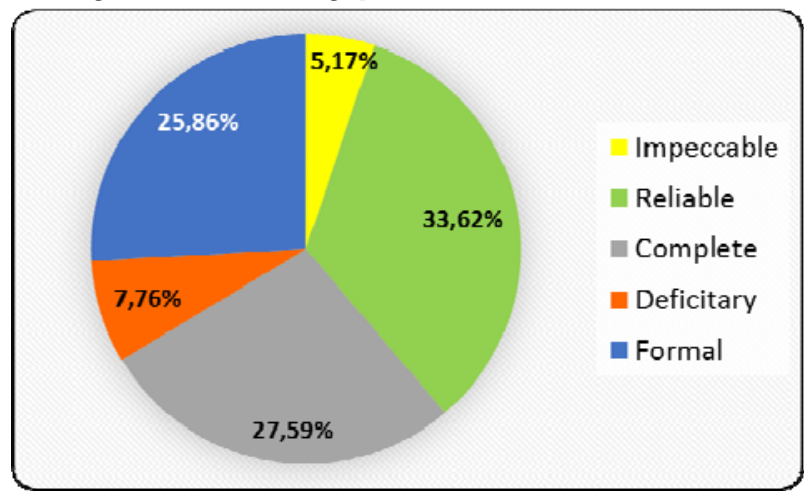

Source: Own projection

There can only be classified as worrying the fact that over $25 \%$ of the respondents feel the audit evidence as being formal and almost $8 \%$ perceive them as being deficitary. But, in our opinion, the explanation is a complex one, depending, firstly, not only on the professionalism of the public internal auditors and on their power of persuasion, but also on a less developed culture of the respondents.

In order to assess the influence of the representatives of the financial and accounting departments on the audit opinion, we inserted in our survey four questions through which we wish to identify: if there were situations in which the respondents observations upon the internal audit report draft had the effect of modifying this document; the frequency with which the internal audit report draft was changed as a result of the recommendations made by the audited structure; the causes that determine the formulation of recommendations for amending the public internal audit report draft; the extent to which the findings issued through the public internal audit reports reflect the reality.

By processing the collected responses to these four questions, we drew the conclusions presented in the followings.

The respondents' comments regarding the public internal audit report draft had the effect of modifying it in $41.38 \%$ of the cases, while a percentage of $58.62 \%$ of the respondents declared their points of view had no influence on this document.

The respondents declared, therefore, in a significant percentage that their comments on the public internal audit report draft had the effect of modifying it. In this context it is interesting to find out how often the public internal audit report draft was changed as a result of the recommendations made by the audited structure. The results of such an analysis reveal that public internal audit report drafts were rarely modified on the recommendations of the audited structure from the perspective of 
$52.59 \%$ of the respondents, while $47.41 \%$ of them believe that such changes have occurred frequently.

Regarding the causes that determine the formulation of recommendations for amending the draft of the public internal audit report, most respondents (89 people) declared the need to clarify certain aspects that can be misinterpreted. Also, a number of 27 respondents checked the different interpretation of the law by the auditors and the staff within the audited structure. Instead, 9 people considered that the recommendations for changes are caused mainly by matters regrading the form of the draft of the public internal audit report, while 6 respondents selected, as the essential cause, the fact that the auditors don't know the legislation in force.

Analyzing the measure in which the findings issued through the public internal audit reports reflect the reality, the situation is presented according to Figure 3. We can notice that, according to most respondents (53.45\% - 62 subjects), the findings issued through the public internal audit reports reflect the reality to a large extent.

Figure 3: The graphical representation of the results regarding the measure in which the findings issued through the public internal audit reports reflect the reality

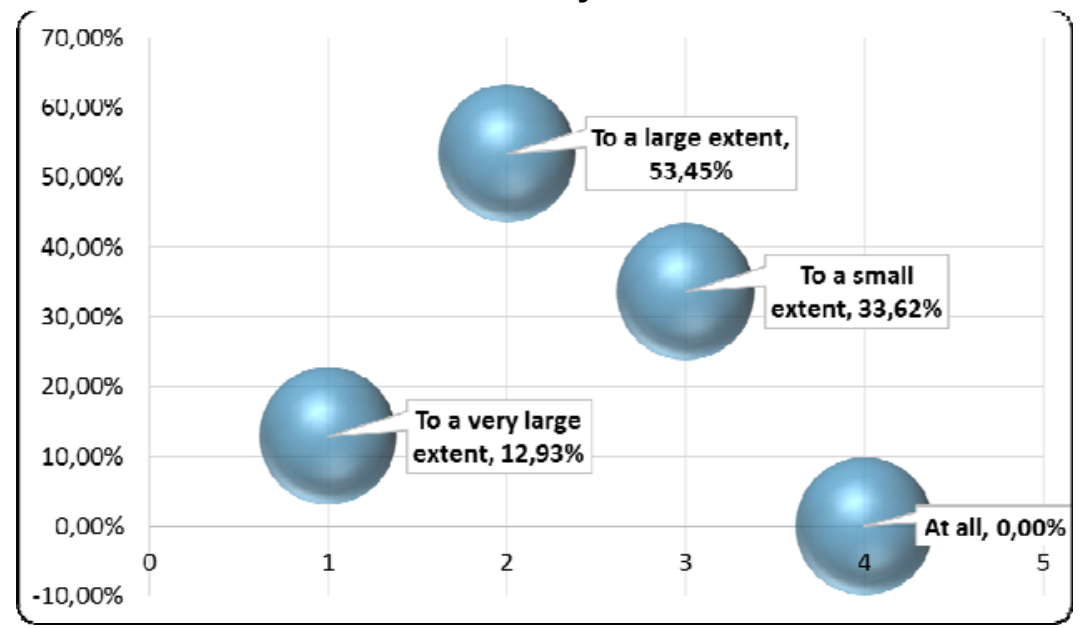

Source: Own projection

We also wanted to know if, at the financial and accounting departments of the universities, were found dysfunctions, as a result of the evaluations made by the public internal audit. The respondents' opinions were divided in the sense that: $53.45 \%$ (62 people) of the respondents stated that, at the accounting and financial departments within the universities, have never been revealed dysfunctions, $43.96 \%$ (51 people) declared that frequent malfunctions were identified, while only $2.59 \%$ (3 persons) believed that these findings occurred very often.

Subjects who responded affirmatively, were asked to clarify to what extent they proceeded, subsequently, to implement the public internal audit department 
recommendations. The summary of the responses collected in this regard is presented in Table 6.

Table 6: The summary of the responses regarding the implementation of the recommendations

If you answered affirmative, please indicate to what extent was subsequently proceed to implement the recommendations of the public internal audit department:

\begin{tabular}{|c|c|c|}
\hline Answer options & $\begin{array}{c}\text { Number of } \\
\text { answers }\end{array}$ & Share \\
\hline The recommendations were fully applied and implemented & 70 & $60,34 \%$ \\
\hline The recommendations were partially applied and implemented & 46 & $39,66 \%$ \\
\hline The recommendations were not applied and implemented & 0 & $0,00 \%$ \\
\hline Total & $\mathbf{1 1 6}$ & $\mathbf{1 0 0 , 0 0 \%}$ \\
\hline
\end{tabular}

Source: Own processing

We can not overlook the major proportion (about 53\%) of those who responded that in their structures the matters are impeccable. We appreciate that we are in an area with relatively subjective responses or in a situation of a lack of performance of public internal auditors in the Romanian universities.

One last point, which we followed via the questionnaire, focuses on the respondents' views on the extent to which the public internal audit activity within the universities contributes to improve the accounting system and its reliability. To find this information, we formulated question no. 18, compulsory for all respondents. The results collected through the questionnaire for this question show that $30.17 \%$ of the respondents believe that the public internal audit activity within the universities contributes in a relative manner to improve the accounting system and its reliability. Also, $23.28 \%$ consider that the audit has a big contribution, $19.83 \%$ declare that it has a reduced contribution, $14.66 \%$ think that it has a very large contribution and $12.06 \%$ of the respondents believe that it has a very weak contribution.

\section{Conclusions}

The research conducted based on the questionnaire made possible the recognition of the perception of the accounting structures representatives from universities, on the impact of the public internal audit on the accounting system and its reliability. Equally, this investigative approach enabled us a better understanding of the pragmatic side of the public internal audit activity, at the level of the accounting structures from the Romanian academic education institutions.

By reporting to the hypotheses initialy established, the results of this empirical research are as it follows:

- although there is a legal provision in this way, there are public institutions of academic education in which the accounting system and its reliability are not audited with a frequency of at least once every three years; 
- the internal auditing of the accounting system and its reliability presents high importance;

- the internal audit activity within universities manages to provide more reasonable assurances regarding the compliance with the regulations in force and less on the accounting system performance;

- from the perspective of most subjects, the requirements of the internal/managerial control standards are always pursued within the framework of the public internal audit missions conducted at the accounting structures level;

- between the elements on the accounting system to be prioritary audited are included not only the receivables and debts accounting, the personnel costs accounting, but also subsidies accounting and treasury accounting;

- the professional training of the internal auditors within universities leaves a lot of place for improvement;

- $\quad$ public internal audit reports drafts are relatively frequently modified, as a result of the recommendations made by the audited structure, from the need to clarify certain aspects that can be interpreted;

- the findings issued through audit reports reflect, to a large extent, the reality;

- not very performant, but at the level of the accounting departments within universities were rarely found dysfunctions, as a result of the assessment made by the public internal audit;

- the public internal audit activity contributes, only in a relative way, to improve the accounting system and its reliability.

In light of the responses obtained, we can notice that, from the ten hypotheses issued, eight were confirmed (hypotheses 2-3, 5-10), while one was partially confirmed (hypothesis 4) and one was denied (hypothesis 1) because, in these latter two cases, the results either were not corresponding or matched our expectations only partially. Overall, we conclude, expressing our view that the results obtained have led us to achieve the objectives proposed for the undertaken study.

\section{References}

Asandului, L.; Niculescu-Aron, I.; Ceobanu, C. (2008) Statistica în educaţie, Editura Universităţii „Alexandru Ioan Cuza”, Iaşi.

Bielińska-Dusza, E. (2011) Analysis of Internal Audit Functioning in Poland - Empirical Research Findings, Business, Management and Education, 9(2), p. 236-247.

Ştefănescu, A., Turlea, E. (2009), Internal Audit and Risk Management in Public Sector Entities, Between Tradition and Actuality, Annales Universitatis Apulensis Series Oeconomica, 11(1), p. 210-217.

Zakaria, Z., Selvaraj, S.D., Zakaria, Z. (2006) Internal Auditors: Their Role in the Institutions of Higher Education in Malaysia, Managerial Auditing Journal, 21(9), p. 892-904. 